\title{
TITLE:
}

\section{ON SOME YEASTS FROM THE ANTARCTIC REGION}

$\operatorname{AUTHOR}(\mathrm{S})$ :

Soneda, Masami

\section{CITATION:}

Soneda, Masami. ON SOME YEASTS FROM THE ANTARCTIC REGION. SPECIAL PUBLICATIONS FROM THE SETO MARINE BIOLOGICAL LABORATORY 1961, 1(15): 1-10

\section{ISSUE DATE:}

1961-03

URL:

http://hdl.handle.net/2433/176445

RIGHT: 
SPECIAL PUBLICATIONS FROM THE SETO MARINE BIOLOGICAL LABORATORY

\author{
BIOLOGICAL RESULTS \\ $\mathrm{OF}$ \\ THE JAPANESE ANTARCTIC RESEARCH EXPEDITION \\ 15.

\section{ON SOME YEASTS FROM THE ANTARCTIC REGION}

BY

\title{
MASAMI SONEDA
}

NAGAO INSTITUTE 380, MISHUKU, SETAGAYA-KU, TOKYO

SIRAHAMA, WAKAYAMA-KEN

JAPAN

MARCH 1961 
SPECIAL PUBLICATIONS FROM THE SETO MARINE BIOLOGICAL LABORATORY

BIOLOGICAL RESULTS

OF

THE JAPANESE ANTARCTIC RESEARCH EXPEDITION

15.

\section{ON SOME YEASTS FROM THE ANTARC'TIC REGION}

BY

\section{MASAMI SONEDA}

NAGAO INSTITUTE

380, MISHUKU, SETAGAYA-KU, TOKYO

SIRAHAMA, WAKAYAMA-KEN

JAP A N

MARCH 1961 
This series contains THE BIOLOGICAL RESULTS OF THE JAPANESE ANTARCTIC RESEARCH EXPEDITION and is published by the Seto Marine Biological Laboratory. Parts will appear at irregular intervals as they become ready.

PRINTED IN JAPAN

BY NIPPON PRINTING AND PUBLISHING Co., Ltd.

HUKUSIMA, OSAKA

Issued March 20, 1961 
$\mathrm{A}^{\mathrm{S}}$ far as ascertained, the report of the yeasts from the Antarctic region could not be found. However, the present author isolated five species of yeasts from some soily materials of the Antarctic region which were collected by Dr. H. Fukushima, Dr. R. HAGA and Dr. T. Matsuda, all were the members of the 3rd and 4th Japanese Antarctic Research Expedition. The results of the isolation are shown in Table 1. The isolation was followed to the ordinary agar-plating method; soil-suspension was poured on the malt-agar plates and kept at $20^{\circ} \mathrm{C}$.

Table I. Yeasts from the Antarctic materials.

\begin{tabular}{|c|c|c|c|}
\hline Yeast isolated & \multicolumn{2}{|c|}{ Place (date) } & Number of strain \\
\hline Cryptococcus albidus & West Ongul Isl. & $\left(4 t^{\prime}\right)$ & 1 \\
\hline Cryptococcus laurentii & Showa Base & (3rd) & 1 \\
\hline " & $\begin{array}{l}\text { Showa Base, the } \\
\text { and West Ongul }\end{array}$ & $\begin{array}{l}\text { ent } \\
\text { (4th) }\end{array}$ & 4 \\
\hline Rhodotorula mucilaginosa & $\begin{array}{l}\text { the Continent an } \\
\text { West Ongul IsI. }\end{array}$ & (4th) & 5 \\
\hline Torulopsis famata & Showa Base & $(3 r d)$ & 1 \\
\hline Trichosporon cutaneum & Showa Base & (3rd) & 1 \\
\hline
\end{tabular}

Among the above five species, Cryptococcus laurentii and Rhodotorula mucilaginosa were dominant members.

The present author has some doubt that all members of yeasts, here treated, existed in the Antarctic soil when collected and they are also present there even now. But it should be speculated that above two dominant species may present in soil of the Antarctic region, and they can grow under lower temperative condition as far as tested.

On relationships between yeasts and low-temperature, HANSEN $(1881,1903)$ demonstrated that yeasts are often very resistant to the cold; LOCHHEAD and FARRELL (1930) reported that some yeasts could remain viable in the soil of Canadian winter; STILLE (1950) examined that yeast cells are not destributed at $-195^{\circ} \mathrm{C}$ under the same operation; LUND (1954) examined that yeast survived freezing in grape juice several months under the same condition.

Cryptococcus albidus (SAIto) SKInNer, in HenRICI's Molds, yeasts and Actinomycetes, 2nd ed. p. 288. (1947)

syn. Torula albida Sarto.

Morphological properties: After 3 days in malt extract at $20^{\circ} \mathrm{C}$, cells are 
usually spherical $(3.0 \sim 8.0) \times(3.0 \sim 8.0) \mu$, single or in pairs (Fig. 1), a sediment and thin ring are formed, the cells are surrounded by capsule; after one month, a ring and sediment are present.

After one month on malt agar at $20^{\circ} \mathrm{C}$, the colony is yellowish white to white, somewhat bullated, soft, mucous and slightly shiny.

Physiological properties: Oxidative; Assimilate glucose, galactose, maltose, saccharose, lactose and ethanol; potassium nitrate is well assimilated; not split arbutin; starch like compounds is formed in capsule.

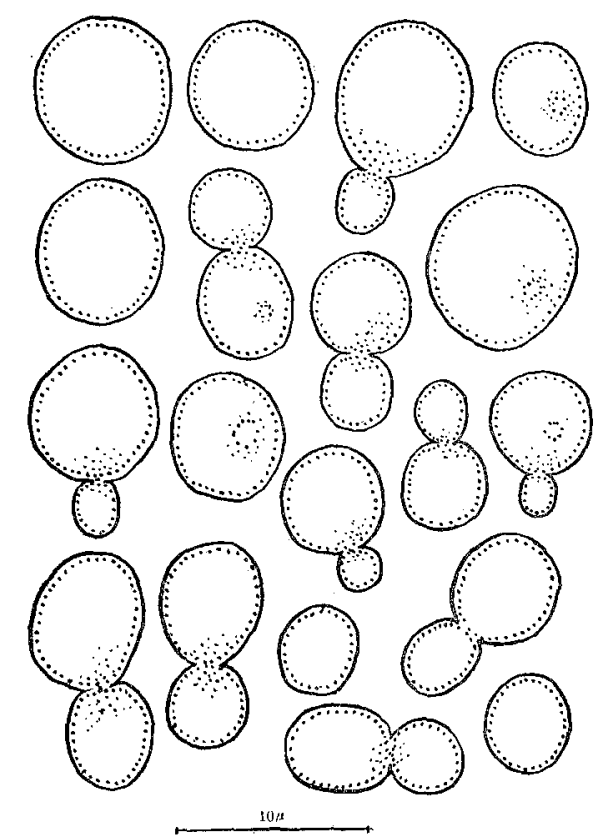

Fig. 1. Cryptococcus albidus (Antarctic strain) 3 days in malt extract.

This strain is different from the original description of SAITo (1922) on assimilation of potassium nitrate, but LODDER (1934) examined the above SAITo's strain and found that it assimilated potassium nitrate.

Cryptococcus laurentii (KUFFERATH) SKINNER, in HENRICI's Molds, yeasts and Actinomycetes, 2nd ed. p. 288 (1947)

syn. Torula laurentii Kufferath.

Morphological properties: After 3 days in malt extract at $20^{\circ} \mathrm{C}$, growth is slow, cells are almost ovoid or seldom ameboid, $(3.0 \sim 7.2) \times(3.2 \sim 8.6) \mu$, single or in pairs (Fig. 2), a sediment is formed, after one month at $20^{\circ} \mathrm{C}$, thin ring and slimy sediment are produced. The cells are surrounded by capsule. 
On some yeasts from the Antarctic region

After one month on malt agar at $20^{\circ} \mathrm{C}$, the color is whitish yellow to light orange, soft, slimy, smooth and somewhat glistening; margin smooth.

Slide culture on potato agar at $20^{\circ} \mathrm{C}$, usually no pseudomycelium, seldom few large polymorphous cells are observed.

Physiological properties: Oxidative; glucose, galactose, maltose and saccharose are assimilated, lactose and ethanol are not assimilated; potassium nitrate is not assimilated; arbutin is not splitted; starch-like compound is formed.

This strain characteristically can grows at lower temperature; maximum temperature is $20^{\circ} \mathrm{C}$, grows at $5^{\circ} \mathrm{C}$ after 7 days. This strain has sometimes developed ameboidal cells in malt extract, which resemble those of Crytococcus

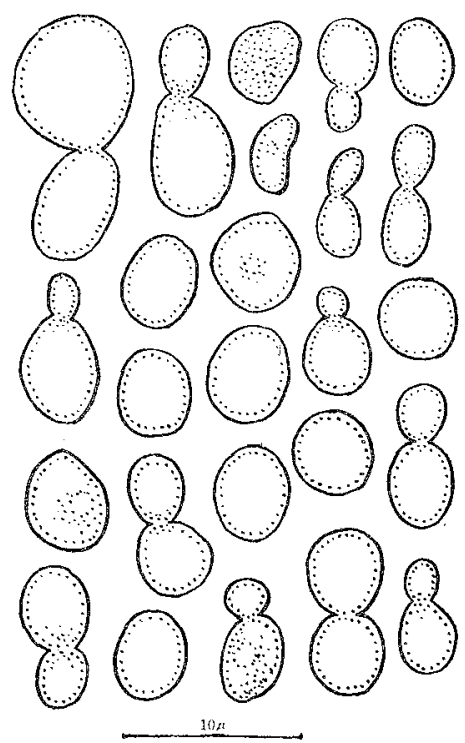

Fig. 2. Cryptococcus laurentii (Antarctic strain) 3 days in malt extract.

laurentii var. flavescens; shape and size of the cells are ranked between that of Cryptococcus laurentii and Cryptococcus laurentii var. magnus. However, the present author gave the name, Cryptococcus laurentii, for this strain, because this two features are not so important for yeast classification.

Rhodotorula mucilaginosa (JoRG.) HARRIson, in Trans. Roy. Soc., V, $22: 187$ (1928) ; Kobayashi, Y., K. Tubaki and M. Soneda, in Bull. Nat. Sci. Mus. (Tokyo) $33: 47$ (1955) ; SONEDA, M., in Nagaoa 6:14 (1959).

syn. Torula mucilaginosa SaIto.

Morphological properties: After 3 days at $25^{\circ} \mathrm{C}$, cells are almost ovoid $(2.8 \sim 4.2) \times(4.0 \sim 7.2)$, single or in pairs, (Fig. 3) a sediment and a ring are for- 
med, after one month at $20^{\circ} \mathrm{C}$ the ring becomes thicker and pinkish color.

After one month at $20^{\circ} \mathrm{C}$ on malt agar, the streak is soft, smooth and somewhat mucous; the color of streak is red to whitish red; margin smooth.

Physiological properties: Oxidative; glucose, galactose, maltose, saccharose and ethanol are assimilated, lactose is not assimilated; potassium nitrate is not assimilated: arbutin is not splitted.

The characteristics of this strain resemble the original description of JöRGENSEN (1909) and also the standard description of LODDER and KREGER-VAN RIJ (1952), but optimum temperature of the present strain for the growth is rather low; it is $20^{\circ} \mathrm{C}$ as far as tested.

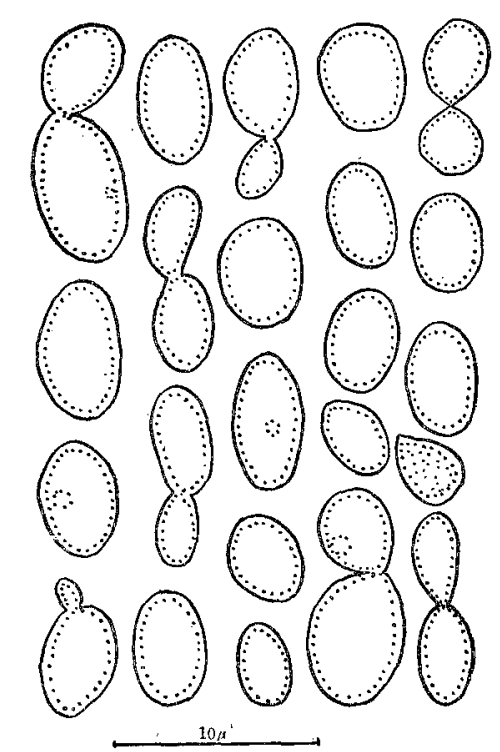

Fig. 3. Rhodotorula mucilaginosa (Antarctic strain) 3 days in malt extract.

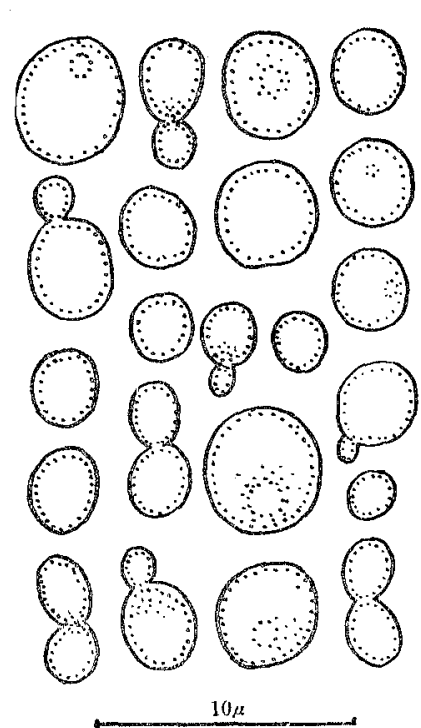

Fig. 4. Torulopsis famata (Antarctic strain) 3 days in malt extract.

Torulopsis famata (Harrison) Lodder et K-vaN RIJ, The Yeasts, p. 417 (1952) ; SONEDA, M., in Nagaoa 6 : 13 (1959).

syn. Mycotorula famata HARRISON.

Morphological properties: After 3 days in malt extract at $25^{\circ} \mathrm{C}$, cells are spherical or ovoid, $(2.0 \sim 4.8) \times(2.2 \sim 5.2) \mu$, single or in pairs (Fig. 4), after one month at $20^{\circ} \mathrm{C}$, sediment and a ring are produced.

After one month on malt agar at $20^{\circ} \mathrm{C}$, the colony is whitish or yellowish white, almost smooth, only with some radial stripes, soft and not much glistening; margin smooth.

Slide culture on potato agar, pseudomycelial cells are not observed.

Physiological properties: Oxidative; glucose, galactose, maltose and saccharose 
On some yeasts from the Antarctic region

are assimilated, lactose is not assimilated; potassium nitrate is not assimilated.

This strain resembles the original description of HARRISON (1928) on morphological and physiological properties.

Trichosporon cutaneum (DE BEURM, GOUGEROT et VAUCHER) OTA, in Ann. parasitol, humaine et Copée 4:1 (1926); SoNEDA, M., in Nagaoa 6:15 (1959).

syn. Oidium cutaneum DE BEURM, GoUgerot et VAucher.

Morphological properties: After 3 days in malt extract at $20^{\circ} \mathrm{C}$, cells are spherical, ovoid and cylindrical, $(2.4 \sim 7.0) \times(4.2 \sim 10.0) \mu$, but may be longer, single or in pairs (Fig. 5), occasionally pseudomycelial cells and arthrospores appear, after one month at $20^{\circ} \mathrm{C}$, the culture consists of thick, tough, wrinkled pellicle and membraneous sediment.

After one month on malt agar at $20^{\circ} \mathrm{C}$, the steak is dry, dull, not hairly, raised, whitish yellow to brownish white and wrinkled.

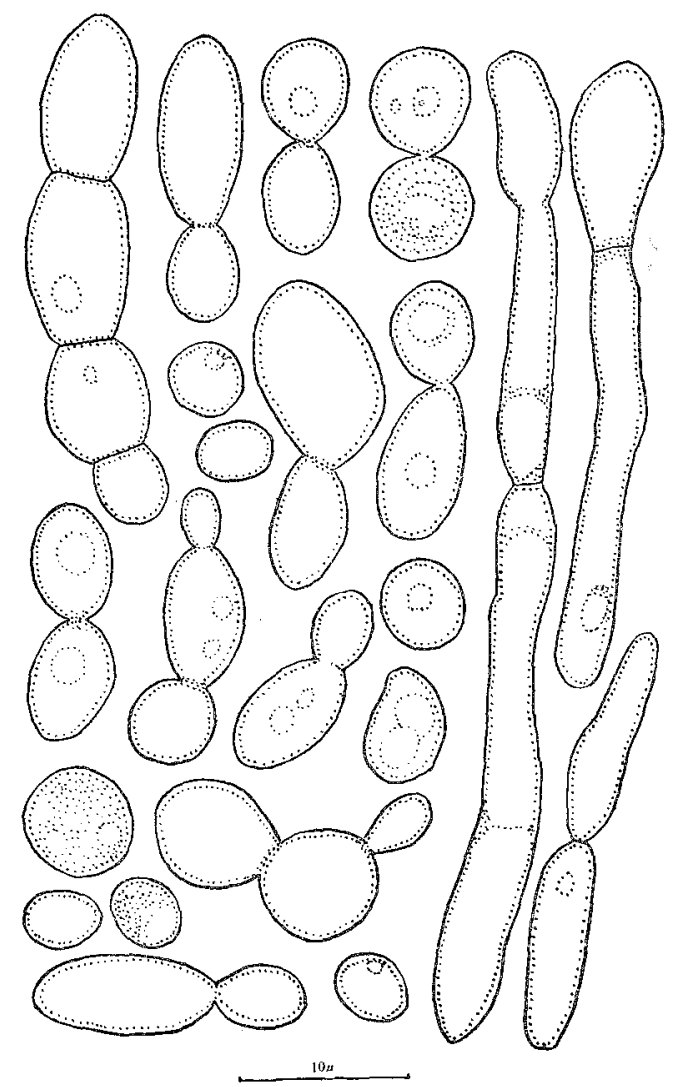

Fig. 5. Trichosporon cutaneun (Antarctic strain) 3 days in malt extract. 
Slide culture on potato agar, the pseudomycelium, arthrospores and blastospores are developed abundantly. Chains of spherical or cylindrical cells occur on pseudomycelium, and it is splitted up into variable length arthrospores that may give raised to a zig-zag formation (Fig. 6). Sometimes large polymorphous cells are formed at intercalery cells.

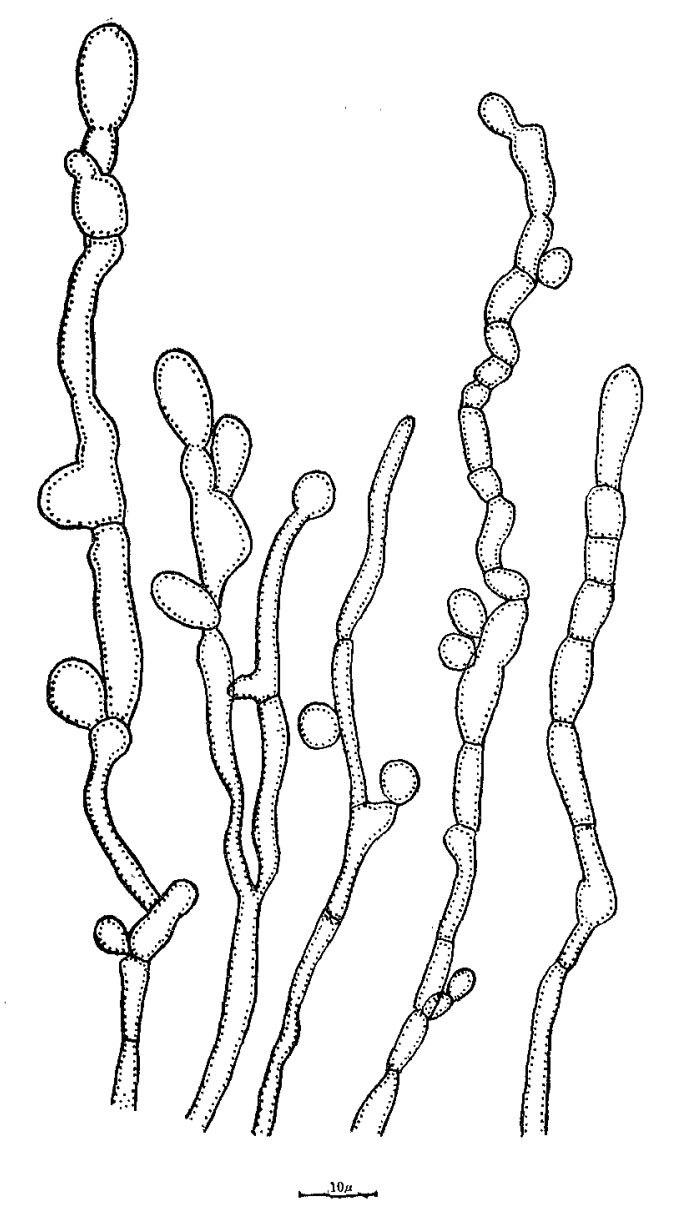

Fig. 6. Trichosporon cutaneum (Antarctic strain) Slide culture on potato agar after 7 days.

Physiological properties: Oxidative; assimilate glucose, galactose, maltose, saccharose and lactose; potassium nitrate is not assimilated; ethanol is not assimilated ; under appropriate conditions "Starch-like compounds" is formed.

This strain is not so different from the standard description of LODDER et KREGER-VAN RIJ, but growth on malt agar is more or less reduced, and optimum temperature for the growth is $20^{\circ} \mathrm{C}$. 
On some yeasts from the Antarctic region

\section{RESULTS AND DISCUSSION}

It seems to be difficult to decide whether these yeasts, originally isolated from the above Antarctic materials, may present in the Antarctic or not. But the high rate of the isolation and the growth under lower temperature may suggest the important problems for discussing the ecology of these Antarctic yeasts. Table II shows the rate of the comparative growth between the Antarctic strains and the strains which are presenting in our collection.

Table II. Effect of temperature for growth.

(After 7 days on malt agar)

\begin{tabular}{|c|c|c|c|c|c|}
\hline Species Temp. & $5^{\circ} \mathrm{C}$ & $12^{\circ} \mathrm{C}$ & $20^{\circ} \mathrm{C}$ & $25^{\circ} \mathrm{C}$ & $30^{\circ} \mathrm{C}$ \\
\hline $\begin{array}{cr}\text { Cr. laurentii (Antarctic strain) } \\
", \quad \text { (NI. 7353) }\end{array}$ & + & + & $\begin{array}{l}+1- \\
+1\end{array}$ & - & - \\
\hline $\begin{array}{c}\text { Rh. mucilaginosa (Antarctic strain) } \\
", \quad \text { (NI. 7203) }\end{array}$ & $\frac{1}{1}$ & $\begin{array}{l}+ \\
+\end{array}$ & $\begin{array}{l}\text { Ht } \\
+1\end{array}$ & $\begin{array}{l}-1 \\
-H\end{array}$ & - \\
\hline $\begin{array}{c}\text { Trich. cutaneum (Antarctic strain) } \\
", \quad \text { (NI. 7461) }\end{array}$ & - & \# & $\begin{array}{l}H \\
H\end{array}$ & $\begin{array}{l}\text { H } \\
H\end{array}$ & +H \\
\hline $\begin{array}{c}\text { Cr. albidus (Antarctic strain) } \\
", \quad \text { (NI. 7349) }\end{array}$ & - & $\begin{array}{l}1 \\
+\end{array}$ & $\begin{array}{l}H \\
H\end{array}$ & $\begin{array}{l}H \\
H\end{array}$ & - \\
\hline $\begin{array}{r}\text { T. famata (Antarctic strain) } \\
", \quad \text { (NI. 7577) }\end{array}$ & - & $\begin{array}{l}\frac{1}{1} \\
+\end{array}$ & $H$ & $\begin{array}{l}\text { Ht } \\
\text { itt }\end{array}$ & $\begin{array}{l}+ \\
+\end{array}$ \\
\hline
\end{tabular}

The result indicates that these Antarctic yeasts may be divided into the following three groups from view-point of their minimum, optimum and maximum temperature.

(1) Optimum temperature of growth is $20^{\circ} \mathrm{C}$; growth well at even $5^{\circ} \mathrm{C}$.

(2) Optimum temperature of growth is $20^{\circ} \mathrm{C}$; can not grow at $5^{\circ} \mathrm{C}$.

(3) Optimum temperature is about $25^{\circ} \mathrm{C}$; can not grow at $5^{\circ} \mathrm{C}$; not so different from type strain.

Cryptococcus laurentii and Rhodotorula mucilaginosa may be included in (1); minimum, optimum and maximum temperature of these strains are lower as compared with other strains of type cultures.

Trichosporon cutaneum is in (2); it grows under low-temperative condition as compared with other the two species, Cryptococcus albidus and Torulopsis famata.

Many thanks are due to Dr. Y. Kobayasi and Dr. K. TuBAKI for their instructions and advices, and also to Dr. H. FukushrmA, Yokohama Municipal University, for giving the materials. 


\section{SUMMARY}

(1) Five species of yeasts were isolated from soily materials of the Antarctic region, collected by members of the 3rd and 4th Japanese Antarctic Research Expedition.

(2) Cryptococcus laurentii and Rhodotorula mucilaginosa seem to be dominant species among them and can grow at lower temperature as far as tested.

\section{LITERATURE CITED}

Coor, A. H. 1958. The chemistry and biology of yeasts.

Hansen, E. C. 1881. Medd. Carsberg Lab. 1, 293.

1903. Centr. Bakt. Parasitenk Abt. II, 10, 1.

Lochenead, A. G. and Farrell, L. 1930. Can. J. Research, 3, 51.

LODDER, J. and KREGER VAN-RIJ, N. J. W. 1952. The yeasts.

LUND, A. 1954. Studies on ecology of yeasts.

SonedA, M. 1959. Nagaoa, 6:1-23.

StIlle, B. 1950. Arch. Mikrobiol. 14, 554.

Postscript; Since this manuscript went to press, M. E. DI MENNA has published a paper on the Antarctic yeasts "Yeasts from Antarctic", in Jour. Gen. Microbiol. 23 : 295-300. 1960) in which she described eight species of yeasts, Candida, Cryptococcus, Rhodotorula and Sporobolomyces. 


\section{BIOLOGICAL RESULTS}

$\mathrm{OF}$

THE JAPANESE ANTARCTIC RESEARCH EXPEDITION

1. Tanita, Senji: Sponges. 8 pp.

May 1959

2. NAKASEKo, Kojiro: On Superfamily Liosphaericae (Radiolaria) from sediments in the sea near Antarctica (On Radiolaria from sediments in the sea near Antarctica. Part 1). 13 pp., 3 pls.

May 1959

3. Hirano, Minoru: Notes on some algae from the Antarctic collected by the Japanese Antarctic Research Expedition. 13 pp., 3 pls.

May 1959

4. Hatal, Kotora: A new rhynchonellid (Brachiopoda) from Antarctica. 7 pp.

May 1959

5. TokiokA, Takasi : Amaroucium erythraeum Michaelsen, a compound ascidian from the Cape Province. 6 pp.

May 1959

6. Yosir, Riozo: Collembolan fauna of the Cape Province, with special reference to the genus Seira Lubbock. 24 pp.

June 1959

7. Gamô, Sigeo: On a cumacean Crustacea (Diasiylis corniculatus Hale) obtained by the Second Japanese Antarctic Research Expedition (1957-58). 7 pp.

October 1959

8. Utinomi, Huzio: Pycnogonida of the Japanese Antarctic Research Expeditions 1956-1958. 12 pp.

December 1959

9. Matsubara, Kiyomatsu and IwaI, Tamotsu: Fishes. 7 pp., 1 pl. December 1959

10. Tanaka, Otohiko: Pelagic Copepoda. 95 pp., 40 pls.

March 1960

11. Uchіо, Takayasu: Planktonic Foraminifera of the Antarctic Ocean. 9 pp., 1 pl.

May 1960

12. Uchro, Takayasu: Benthonic Foraminifera of the Antarctic Ocean. 19 pp., 1 pl.

May 1960

13. Kobayasi, Yosio: An imperfect lichen found in the Antarctica. 7 pp. March 1961

14. Tubakr, Keisuke: On some fungi isolated from the Antarctic materials. 9 pp.

March 1961

15. Soneda, Masami : On some yeasts from the Antarctic region. 1961. $10 \mathrm{pp}$.

March 1961 